\title{
WYKORZYSTANIE CYFROWEJ MAPY TURYSTYCZNEJ DO WSPIERANIA ROZWOJU TURYSTYKI NA OBSZARACH WIEJSKICH NA PRZYKLADZIE GMIN WIEJSKICH WOJEWÓDZTWA LÓDZKIEGO
}

\begin{abstract}
Zarys treści: Wraz z postępem technologicznym i zmianami potrzeb obecnych użytkowników map duże znaczenie zaczynają odgrywać cyfrowe mapy umieszczane w Internecie. Tego typu mapy stają się atrakcyjnym produktem turystycznym wielu regionów. Artykuł miał na celu sprawdzenie wykorzystania cyfrowych map turystycznych na terenach wiejskich województwa łódzkiego. Została podjęta próba analizy cyfrowych map turystycznych gmin wiejskich województwa łódzkiego umieszczonych w Internecie. Scharakteryzowano serwisy o zasięgu ogólnopolskim, wojewódzkim oraz lokalnym. Szczegółowo zbadano mapy gmin umieszczone na ich własnych stronach internetowych, a wyniki kwerendy przedstawiono na mapach.
\end{abstract}

Słowa kluczowe: Cyfrowa mapa turystyczna, interaktywna mapa cyfrowa, turystyka na obszarach wiejskich, województwo łódzkie.

\section{Wprowadzenie}

Otaczająca nas wszystkich rzeczywistość od dawna opisywana jest za pomocą map, które pełniły funkcję informacyjną oraz orientacyjną. Zgodnie z definicją Jerzego Gaździckiego, mapa to ,model rzeczywistości geograficznej przedstawiony w postaci graficznej (...) z zastosowaniem skali i zrozumiałej dla użytkownika symboliki kartograficznej" (Gaździcki 2001: 48). Do niedawna za najbardziej rzetelne źródło informacji i najlepsze odzwierciedlenie przestrzeni uważano mapy papierowe, co powodowało, że były one najczęściej używane. Dzisiaj do zobrazowania otaczającej nas rzeczywistości wykorzystuje się także systemy informacji geograficznej, które umożliwiają zebranie oraz dalsze analizowanie danych pochodzących z wielu dziedzin, a następnie ich wizualizację (Gotlib, Iwaniak, Olszewski 2007). Rozwój Internetu oraz technologii cyfrowych wymusił zmiany w kartografii, w tym największe w sposobie i zakresie korzystania z map 
i atlasów. Obecnie coraz bardziej popularne stają się mapy cyfrowe, które ze względu na łatwą dostępność, różnorodność oraz atrakcyjność przekazu zyskują wielu zwolenników (Kowalski 2012).

Mapa cyfrowa to „model rzeczywistości geograficznej przedstawiony w postaci cyfrowej i przystosowany do komputerowego przetwarzania danych geograficznych oraz generowania map analogowych określonego obszaru" (Gaździcki 2001: 49). Mapa cyfrowa różni się od papierowej większą ilością informacji, między innymi na temat geometrii, właściwości czy cech obiektów, które umieszczone są w bazie danych (Davis 2004). W Internecie pojawia się coraz więcej serwisów tematycznych zawierających opracowania kartograficzne i cyfrowe mapy, które najczęściej wykorzystywane są w turystyce (Jaworska 2014). Bardzo ważna jest aktualność map oraz ich użyteczność na stronach internetowych, gdzie mapa powinna posiadać cechy, takie jak interaktywność oraz hipermedialność, które wzbogacają jej funkcjonalność (Kowalski 2012). Użyteczność mapy rozumiana jest poprzez jej intuicyjność, efektywność i przyswajalność, czyli inaczej łatwość w obsłudze, szybkość w wykonywaniu określonych czynności i niepodatność na błędy (Nielsen 2003).

Wśród cyfrowych map umieszczonych w Internecie wyróżnić można mapy ilustracyjne oraz mapy funkcyjne. Mapy te różnią się sposobem funkcjonowania na stronie internetowej. Mapy ilustracyjne to statyczne mapy, a mapy funkcyjne wyposażone są dodatkowo w określone funkcje interaktywne. Różnica pomiędzy mapami ilustracyjnymi a funkcyjnymi powoduje zmiany w ocenie ich użyteczności. W przypadku map funkcyjnych, oprócz treści kartograficznej, generalizacji, zmiennych graficznych, metody prezentacji kartograficznej, legendy, odwzorowania kartograficznego oraz innych elementów pomocniczych, ocenia się także elementy osnowy funkcyjnej, które wywołują różne akcje, takie jak zmiana wyświetlanych warstw, zmiana parametrów widoku czy odnośniki do innego dokumentu. Istotnym elementem mapy interaktywnej jest interfejs kartograficzny, który powinien być przejrzysty i prosty. Do jego głównych składowych zalicza się panel warstw informacyjnych, paski narzędziowe i narzędzia sterujące, pasek wyboru profili kartograficznych, legendę i etykiety tekstowe (Kowalski 2012). Mapy ilustracyjne, do których zalicza się mapy numeryczne oraz rastrowe kopie map drukowanych są najczęściej spotykanymi mapami na stronach internetowych ze względu na prosty sposób udostępniania materiałów kartograficznych w Internecie (Kowalski 2012). Mapy ilustracyjne nazywa się także mapami statycznymi, gdzie mapa rozumiana jest jako plik rastrowy, opublikowany w Internecie, najczęściej w formacie jpg lub png, prezentujący mapę umieszczoną na stronie internetowej. Mapa statyczna nie posiada właściwości interaktywnych, przez co jest mniej ciekawa, ale prosta do wykonania edycji, a także umieszczenia na stronie internetowej (Longley i in. 2006). Mapy te wykonywane są głównie w celach informacyjnych, lokalizacyjnych oraz marketingowych. Najbardziej popularne 
mapy ilustracyjne to mapy pogody, mapy komunikacyjne, a także mapy umieszczane w publikacjach naukowych i gospodarczych (Kowalski 2000). Dzięki postępowi technologicznemu, z którym wiąże się rozwój serwerów mapowych oraz aplikacji webowych nastąpił rozkwit cyfrowych map interaktywnych łączących zalety tradycyjnej mapy z wymaganiami współczesnego użytkownika. Mapy te posiadają funkcjonalność typową dla systemów informacji geograficznej, przez co pozwalają na wykonywanie różnych operacji, m.in.: wyświetlania, powiększania i pomniejszania, wyszukiwania, wykonywania pomiarów (Kowalski 2012). Systemy informacji geograficznej to inaczej „systemy informacji przestrzennej dotyczące danych geograficznych" (Gaździcki 2001: 87). Za system informacji przestrzennej uważa się system pozyskiwania, przechowywania, sprawdzania, analizowania oraz udostępniania danych przestrzennych. Takim systemem może być oprogramowanie posiadające wymienione funkcje bądź w szerokim rozumieniu metody, sprzęt, oprogramowanie, baza danych przestrzennych, finanse, a także ludzie zajmujący się jego wykorzystaniem (Gaździcki 2001). Mapa interaktywna to aplikacja sieciowa wyświetlająca treść kartograficzną. Zwykle jest to mapa wektorowa, w której interfejs użytkownika pozwala na wykonywanie pewnych operacji, takich jak zmiany widoku - przybliżanie, oddalanie, przesuwanie czy wyświetlanie dodatkowych informacji zarówno tekstowych, jak i zdjęć, filmów i zewnętrznych odnośników. Jest to mapa sporządzona w postaci geoportalu lub za pomocą innych technologii, np. java, flash (Kubik 2009). Poprzez mape wektorową należy rozumieć mapę, gdzie każdy obiekt przedstawiony jest za pomocą odpowiedniego typu geometrycznego: punktu, linii lub wieloboku, którego kształt określają współrzędne. Elementy tego samego typu geometrycznego przechowywane są w bazie danych przestrzennych jako klasy obiektów i posiadają właściwości zapisane w przyporządkowanych im tabelach (Longley i in. 2006).

W dzisiejszych czasach Internetu mapy cyfrowe zyskują na popularności. $\mathrm{Na}$ różnego rodzaju stronach internetowych odnaleźć można wiele map cyfrowych, zarówno prostych, statycznych map, głównie lokalizacyjnych, jak i bardziej zaawansowanych, interaktywnych map oferujących szerokie możliwości funkcjonalne. Mapy te różnią się zarówno tematyką, technologią wykonania, a także wspomnianą już funkcjonalnością.

\section{Cele i metody badań}

Celem artykułu jest przedstawienie wyników badań dotyczących wykorzystania cyfrowych map turystycznych umieszczonych w Internecie przez gminy wiejskie województwa łódzkiego we wspieraniu rozwoju turystyki. Celem pośrednim jest zwrócenie uwagi na gminy, które do rozwoju turystyki na swoim obszarze podchodzą w sposób innowacyjny oferując turystom nowoczesne sposoby poznania własnej oferty turystycznej. 
Badania przeprowadzono w oparciu o kwerendę stron internetowych i analizę prezentowanych map. Kwerendę sporządzono z końcem 2017 roku i objęto nią wszystkie 133 gminy wiejskie województwa łódzkiego. Poszukiwano ogólnodostępnych stron internetowych publikujących turystyczne mapy interaktywne gmin na poziomie ogólnopolskim i regionalnym. Następnie przeszukano strony internetowe urzędów każdej ze 133 gmin oraz zawarte w nich odnośniki. Obliczono odsetek poszczególnych typów map we wszystkich badanych gminach. Podzielone one zostały na interaktywne i statyczne mapy turystyczne. Dodatkowo znaleziono także pozostałe, nieturystyczne mapy tych gmin zamieszczone na ich własnych stronach internetowych, spośród których najczęściej spotykane to proste mapy lokalizacyjne z podziałem administracyjnym, miejscowościami czy siecią drogową, a także fragmenty map topograficznych. Sprawdzono także posiadanie przez gminy własnych systemów informacji przestrzennej.

\section{Turystyka na obszarach wiejskich}

Ważną cechą współczesnej turystyki jest dynamika jej rozwoju przejawiająca się poprzez powstawanie nowych produktów, obiektów, urządzeń i organizacji, które tworzone są na potrzeby turystów. Przez produkt turystyczny rozumie się zbiór użyteczności dotyczących podróży turystycznych, a dokładniej wszystkie dobra i usługi dostępne na rynku pozwalające na planowanie podróży, ich odbywanie i przeżywanie, a także zbieranie różnych doświadczeń. Szczególnie istotne w niniejszym opracowaniu jest przedstawienie kategorii produktu turystycznego jako rzeczy, który może istnieć samodzielnie bądź stanowić dodatek do innych produktów. W tym rozumieniu jest to dobro materialne, takie jak sprzęt turystyczny, przewodniki, mapy turystyczne, a w ostatnim czasie także wszelkie produkty multimedialne, takie jak mobilne przewodniki, interaktywne mapy i plany miast umieszczane na stronach internetowych skierowane głównie dla turystów wirtualnych (Kaczmarek, Stasiak, Włodarczyk 2005).

Badania nad polską wsią mają w geografii długą tradycję i obecnie są bardzo zróżnicowane, ze względu na wieloprzedmiotowy charakter. Wśród pól badawczych geografii wsi znajdują się m.in. użytkowanie ziemi i planowanie przestrzenne, osadnictwo wiejskie, rozwój lokalny czy turyzm i rekreacja (Wójcik 2013). Do pól badawczych jako struktur funkcjonalnych zalicza się rolnictwo, leśnictwo, przemysł i górnictwo, turystykę i rekreację, mieszkalnictwo, usługi, komunikację, infrastrukturę, ochronę środowiska i wielofunkcyjność (Falkowski 2015). Obszary wiejskie zajmują około 80\% powierzchni Unii Europejskiej (Jędrysiak 2010) oraz ponad 93\% powierzchni Polski, na których mieszka ponad 14 mln ludzi (Karnafel-Wyka 2011). Poprzez obszar wiejski rozumie się ,przestrzeń, w której działa człowiek i którą charakteryzuje stosunkowo niska gęstość zaludnienia, rozproszone osadnictwo i ekstensywne zagospodarowanie ziemi” (Jędrysiak 2010: 9). 
Obszary wiejskie tradycyjnie utożsamiane są z rolnictwem. Znaczenie tej funkcji jednak zdecydowanie maleje na rzecz funkcji publicznych oraz funkcji produkcyjnych nierolniczych. Powierzchnia użytków rolnych ciągle maleje i jest przeznaczana dla innych funkcji. Wyróżnić można wiele klasyfikacji funkcji obszarów wiejskich uwzględniających różnorodne kryteria. Jednym z podstawowych podziałów funkcji wsi jest podział na funkcje naturalne, uwzględniające atrybuty przyrodnicze, krajobrazowe i ekologiczne oraz na funkcje antropogeniczne tworzone przez mieszkańców wsi. Istnieje również klasyfikacja funkcji na komercyjne i niekomercyjne, a także na funkcje gospodarcze, przyrodnicze, społeczne i kulturowe. Zwrócić uwagę należy także na uogólnioną identyfikację funkcji kulturowych rolnictwa i wsi. Wyróżnia ona funkcje dotyczące architektury, rolniczej działalności produkcyjnej, utrzymania i konserwacji krajobrazu, pozarolniczej wytwórczości wiejskiej, tradycji kulinarnych oraz obrzędów i twórczości ludowej (Niedzielski 2015). Głównym warunkiem rozwoju obszarów wiejskich jest ich różnorodność. Współcześnie wskazany jest rozwój wielofunkcyjny na obszarach wiejskich. Ze względu na ciągle dominujące na tych terenach rolnictwo konieczny staje się rozwój funkcji pozarolniczych. Na wsiach możliwy jest jednak pełny rozwój tylko kilku funkcji, takich jak m.in. leśnictwo, usługi i handel oraz turystyka (Bański 2004). Wielofunkcyjny rozwój obszarów wiejskich rozumieć należy jako łączenie zwiększonego zatrudnienia w usługach pozarolniczych, wykonywania funkcji umożliwiających rozwój nowych działalności i produkowania dóbr o zwiększonej jakości, urozmaicenie oferty usług oraz ochronę środowiska (Feltynowski 2009).

Turystyka wiejska to złożone pojęcie, które składa się z różnych form rekreacji związanych z przyrodą, aktywnością fizyczną, turystyką kulturową, zdrowotną i krajoznawczą przy pomocy zasobów i walorów turystycznych wsi. Turystyka na terenach wiejskich ulega nieustannym zmianom i przeobrażeniom zarówno podaży, popytu oraz zakresu znaczeniowego samego terminu. Pierwsze terminy turystyki na terenach wiejskich powiązane były z uczestnikami ruchu (ruch letniskowy), następne odnosiły się do miejsca wypoczynku (turystyka wiejska), natomiast najbardziej aktualne odnoszą się do funkcji miejsca (agroturystyka) (Wojciechowska 2006). Różnego rodzaju formy usług turystycznych na obszarach wiejskich stanowią element turystyki wiejskiej lub turystyki na terenach wiejskich, która w zhierarchizowanym układzie pojęć ma najszersze znaczenie (Wojciechowska 2010). Tereny wiejskie w Polsce są atrakcyjne krajobrazowo i kulturowo, ze względu na bogactwo środowiska przyrodniczego, a także tradycje ludowe oraz dziedzictwo kulturowe. Turystyka jest ciągle niedoceniana przez społeczności wiejskie, choć może być dla nich potencjalnym źródłem dochodu, a także szansą na rozwój. Ze względu na uciążliwe warunki życia miejskiego, a dodatkowo postęp technologiczny i poprawę jakości życia na wsi, wieś staje się atrakcyjnym celem wyjazdów urlopowych i weekendowych. Do ważniejszych 
czynników rozwoju turystyki na terenach wiejskich zalicza się: wzrost świadomości o warunkach zdrowotnych na wsi, większe zainteresowanie historią, dziedzictwem kulturowym i tradycją, regionalną kuchnią, rozwój produktu dla turystyki wiejskiej, wzrost poziomu wykształcenia, a także postęp technologiczny i związana z nim poprawa jakości infrastruktury technicznej, środków transportu, wyposażenia rekreacyjnego czy środków masowego przekazu. Każdy region posiada pewne charakterystyczne dla swojego obszaru warunki do rozwoju określonych form turystyki, które są uzależnione od dziedzictwa, kultury, tradycji i bogactwa przyrodniczego danego obszaru (Jędrysiak 2010).

Istotną rolę w rozwijaniu turystyki na określonym terenie pełnią władze lokalne. Ich polityka i aktywność w zakresie turystyki stanowi decydującą kwestię w tym zakresie. Jednostki samorządu terytorialnego posiadają wiele kompetencji w zakresie turystyki. Obecnie zmienia się także podejście do turystyki, która staje się przede wszystkim zjawiskiem ekonomicznym. W gestii gminy, jako podstawowej jednostki podziału terytorialnego kraju, leży zajmowanie się wszystkimi sprawami publicznymi o charakterze lokalnym, którymi nie mają obowiązków zajmować się inne podmioty. Turystyka nie jest zdefiniowana w zadaniach własnych gminy, jednak władze gminy często ją do nich dołączają w zależności od stopnia zainteresowania turystyką na określonym obszarze. Gminy mają także zadania, które są pośrednio związane z turystyką i dotyczą przede wszystkim infrastruktury społecznej i technicznej, zieleni i zadrzewień, ochrony środowiska, porządku publicznego czy ładu przestrzennego (Soliński 2010). Rozwój turystyki w gminie jest uzależniony od rozwoju infrastruktury, bazy turystycznej, a w przypadku gmin wiejskich także od rozwoju agroturystyki. Oprócz tego szczególnie istotna w rozwoju turystyki jest aktywność władz lokalnych, przejawiająca się w tworzeniu klimatu sprzyjającego nowym inwestycjom, a także w działaniach edukacyjnych i informacyjnych. Turystyka jest coraz częściej doceniana przez władze gmin i postrzegana jako szansa na rozwój, szczególnie w gminach atrakcyjnych krajobrazowo oraz gminach posiadających bogatą historię (Marciniuk-Kluska 2014).

Władze samorządowe powinny współpracować zarówno z informacjami turystycznymi, z organizacjami turystycznymi, jak i z prywatnymi przedsiębiorcami zajmującymi się turystyką. Do najbardziej kluczowych działań, jakie gminy powinny podejmować w celu rozwoju turystyki zaliczyć można przystosowanie do potrzeb turystycznych prawa miejscowego, tworzenie wyspecjalizowanych turystycznie podmiotów, rozwój infrastruktury turystycznej, tworzenie klimatu atrakcyjnego pod inwestycje turystyczne, a także edukację turystyczną mieszkańców oraz promocję turystyczną gminy. Szczególnie z ostatnio wymienionymi działaniami związane jest ściśle pojęcie innowacji. Ze względu na istnienie na rynku bardzo wielu różnego rodzaju produktów turystycznych problemem staje się pozostanie konkurencyjnym. Problem ten mogą jednak rozwiązać innowacyjne pomysły i rozwiązania, które pozwolą na wyróżnienie się na rynku. Rozwój 
turystyki jest więc coraz bardziej uzależniony od nowych, kreatywnych produktów turystycznych wraz z odchodzeniem od standardowych, szablonowych rozwiązań (Soliński 2010). W dzisiejszych czasach społeczeństwa informacyjnego i doby Internetu ciekawym produktem oferowanym przez jednostki samorządu terytorialnego może być cyfrowa mapa turystyczna, która może stać się bardzo ważnym źródłem informacji oraz środkiem promocji i edukacji. Internet, obecnie uważany za najbardziej powszechny i skuteczny nośnik informacji, może pomóc również w rozwoju turystyki (Ziółkowski 2007) oraz w zachowaniu i promowaniu dziedzictwa kulturowego (Jażdżewska 2010).

\section{Wyniki badań}

Analiza stron internetowych powiązanych z gminami województwa łódzkiego wskazała, że kluczową rolę w prezentacji interaktywnych map turystycznych gmin odgrywa serwis turystykawgminie.pl. Jest to prywatny serwis turystyczny o charakterze ogólnopolskim publikujący walory turystyczne gmin na jednej platformie wraz z ich wyszukiwarką. Został stworzony dla jednostek samorządu terytorialnego, które chcą promować swoje walory turystyczne w ogólnopolskim serwisie turystycznym. Bezpłatnie udostępnia wizytówki wszystkich gmin w Polsce. Oferuje także możliwość wyświetlania informacji zbiorczych, statystyk o gminach według województw. Serwis ten posiada funkcje interaktywne, takie jak: możliwość zmiany widoku mapy, zmiany treści podkładowych, przełączanie zakładek. Wyróżniono cztery zakładki: atrakcje, szlaki, wydarzenia i noclegi, a każda z zakładek posiada kategorie oznaczone różnymi sygnaturami:

- zakładka atrakcje: wyciąg, przyroda, gastronomia, służba zdrowia, obiekt sakralny, atrakcja, użyteczność publiczna, edukacja, obiekt sportowy,

- zakładka szlaki: pieszy, rowerowy, konny, narciarski, kajakowy,

- zakładka wydarzenia: kulturalne, sportowe,

- zakładka noclegi: pensjonat, pole namiotowe, schronisko, hotel.

W przypadku zakładki noclegi jest możliwość sprawdzenia i wyszukania obiektów stosując filtry zaawansowane, gdzie można dodatkowo prześledzić informacje o ich otoczeniu, warunkach zakwaterowania i dodatkowych atrakcjach. Serwis turystykawgminie.pl przedstawia interaktywne mapy turystyczne wszystkich gmin w Polsce. Jednak ilość i jakość informacji umieszczonych na tych mapach jest niedostateczna. Mapy prezentują niewiele informacji, ograniczając się do kilku najważniejszych atrakcji turystycznych. Pomimo tego, że mapa jest atrakcyjna graficznie i ma prosty interfejs, to brakuje jej zdjęć i informacji $\mathrm{w}$ formie tekstowej o poszczególnych obiektach, co nie pozwala na pełne poznanie oferty turystycznej danej gminy.

Innym serwisem prezentującym mapy turystyczne o zasięgu ogólnopolskim jest portal turystyki aktywnej - map4u.pl. Zarządcą serwisu jest Fundacja Infor- 
matyki i Zarządzania. Zawarte w nim dane możemy wyszukiwać według województw, powiatów, a następnie gmin. Dane podzielone są na poniższe kategorie oraz szereg podkategorii wyświetlanych w zależności od konkretnego obszaru na domyślnym podkładzie map z serwisu Google:

- wycieczki, szlaki,

- zabytki i kultura,

- przyroda i krajobrazy,

- baza noclegowa,

- baza gastronomiczna,

- sport i rekreacja,

- baza towarzysząca,

- miejscowości, obszary,

- artykuły.

Mapy te umożliwiają zmiany widoku, wyszukiwanie lokalizacji obiektów, zmianę podkładu, zmianę zakresu treści mapy poprzez przełączanie wcześniej wymienionych kategorii, wydruk, a dodatkowo pozwalają na wyświetlanie informacji w formie tekstu i zdjęć poszczególnych obiektów. Ponadto jest możliwość wyznaczenia trasy i wskazówek dojazdu do określonego miejsca. Portal ten umożliwia bezpłatne dodawanie własnych obiektów poprzez przesłanie formularza zgłoszeniowego i wypełnienie wszystkich niezbędnych pól, co ułatwia aktualizację danych. Serwis ten oferuje także płatne usługi dla gmin i powiatów wykorzystujące bazy danych serwisu map4u.pl, takie jak indywidualny serwis www, interaktywne mapy cyfrowe w dwunastu tematach, kalendarium i centrum przetwarzania danych, planer, aplikacja mobilna, portal mobilny i kody 2D. Serwis map4u.pl jest użytecznym produktem przedstawiającym interaktywne mapy turystyczne gmin. Swoją atrakcyjność zawdzięcza bogactwu różnorodnych funkcji i możliwości wykorzystania danych zarówno tych płatnych, jak i bezpłatnych. Jednak ilość danych prezentowanych na mapach nie jest wystarczająca ze względu na skupianie się na najważniejszych obiektach danego obszaru. Atrakcyjność serwisu podniosłoby zwiększenie ilości prezentowanej informacji oraz rozbudowanie opisów obiektów, a także większa dbałość o aktualizację danych.

Kolejne trzy serwisy przedstawiają interaktywne mapy cyfrowe województwa łódzkiego. Są to:

- visitlodzkie.pl,

- dev.wsiodle.lodzkie.pl,

- kultura.lodz.pl.

Portal visitlodzkie.pl jest współfinansowany przez Unię Europejską z Europejskiego Funduszu Rozwoju Regionalnego w ramach projektu „Regionalna platforma e-usług publicznych w obszarze kultury i turystyki oraz innych spraw obywatelskich”. Jego zarządcą jest Fundacja Informatyki i Zarządzania. Interaktywna mapa turystyczna tego portalu wykorzystuje te same dane co serwis map4u.pl, 
jednak tylko dla województwa łódzkiego. Obiekty i informację o nich wyświetlać możemy dla całego województwa lub dla poszczególnych powiatów i gmin. Portal ten posiada także taką samą funkcjonalność co portal map4u.pl oraz niewiele różniący się interfejs graficzny.

Portal dev.wsiodle.lodzkie.pl powstał jako część projektu „Turystyka w siodle - infrastruktura innowacyjnego i unikatowego produktu turystycznego" Urzędu Marszałkowskiego Województwa Łódzkiego. Projekt ten miał na celu przygotowanie i budowę infrastruktury Łódzkiego Szlaku Konnego, stworzenie i wdrożenie systemu informatycznego i systemu nawigacji oraz promocję szlaku. „Portal Turystyki Aktywnej w Siodle” jest udostępniony jako zestaw dynamicznych stron www. System informatyczny, oparty na relacyjnych bazach danych, dostarcza turystom m.in. przewodnik po turystycznych szlakach konnych, katalog usług turystycznych i bazę zagospodarowania turystycznego, katalog atrakcji turystycznych, kalendarz imprez i wydarzeń sportowych, kulturalnych i turystycznych. Portal ten jest zintegrowany z bazami danych portalu map4u.pl oraz kultura.lodz.pl. Informacja zawarta na interaktywnej mapie portalu dev.wsiodle.lodzkie.pl i podział na kategorie są takie same jak w przypadku portalu map4u.pl, jednak ograniczone do województwa łódzkiego. Mapa ta posiada także taką samą funkcjonalność jak w przypadku wymienionego już serwisu visitlodzkie.pl oraz bardzo podobny interfejs graficzny.

Ostatnim serwisem prezentującym interaktywną mapę turystyczną dla województwa łódzkiego jest serwis kultura.lodz.pl. Portal jest współfinansowany przez Unię Europejską z Europejskiego Funduszu Rozwoju Regionalnego w ramach zintegrowanego projektu „Wzmocnienie roli Szlaku Bursztynowego i innych szlaków tematycznych w zintegrowanym produkcie turystycznym województwa łódzkiego". Serwis ten może stanowić podstawowy element regionalnego systemu e-informacji kulturalnej, głównie prezentując informacje o zabytkach województwa łódzkiego. Zawiera obiekty umieszczone we wcześniej opisywanych serwisach w kategorii zabytki i kultura. Obiekty z tej kategorii podzielone są na różnorodne podkategorie (tab. 1). Portal posiada taką samą funkcjonalność jak poprzednio opisywane mapy interaktywne oraz bardzo podobny interfejs graficzny. Ilość danych w odniesieniu do poszczególnych gmin nie jest jednak wystarczająca, gdyż uwzględnia tylko najważniejsze zabytki.

Przedstawione interaktywne mapy turystyczne gmin województwa łódzkiego są produktem turystycznym o dużym potencjale rozwoju. Mają prosty, a zarazem przejrzysty interfejs graficzny, a także posiadają wiele funkcji interaktywnych, które podnoszą ich atrakcyjność. Dużą zaletą tych map są zdjęcia większości z zaprezentowanych obiektów, choć część z nich wymaga aktualizacji oraz dodania bardziej szczegółowych opisów tekstowych. Kwestią, na którą należałoby zwrócić uwagę jest także potrzeba zwiększania ilości danych zawartych na tych portalach. 
Tabela 1. Podkategorie serwisu kultura.lodz.pl

\begin{tabular}{ll}
\hline Obiekty archeologiczne & Grodziska, cmentarzyska \\
& Skarby, relikty \\
\hline \multirow{3}{*}{ Zabytki architektury świeckiej } & Układy urbanistyczne \\
& Budynki mieszkalne \\
& Pałace i dwory \\
& Obiekty użyteczności publicznej \\
& Obiekty obronne i warowne \\
& Spichlerze, budynki gospodarcze \\
& Obiekty techniki \\
\hline Miejsca historyczne & Miejsca bitew, męczeństwa \\
& Cmentarze, mauzolea \\
& Pomniki i tablice pamiątkowe \\
\hline Obiekty sakralne & Kościoły, cerkwie, synagogi \\
& Kaplice, kapliczki i krzyże przydrożne \\
& Klasztory, zakony \\
& Inne miejsca kultu \\
\hline Pozostałe walory materialne & Muzea, archiwa i zbiory \\
& Kina, teatry, biblioteki \\
& Centra i ośrodki kultury \\
& Filharmonie, opery, galerie \\
& Fundacje i stowarzyszenia \\
& Inne walory materialne \\
\hline \multirow{2}{*}{ Obiekty kulturalne } & Imprezy kulturalne \\
&
\end{tabular}

Źródło: opracowanie własne

Kolejnym etapem badań była analiza stron internetowych urzędów poszczególnych gmin pod kątem umieszczonych na nich map. Przede wszystkim poszukiwano cyfrowych map turystycznych. Sprawdzono także interaktywne i statyczne pozostałe, nieturystyczne mapy tych gmin.

Najliczniej na stronach internetowych gmin wiejskich województwa łódzkiego występują systemy informacji przestrzennej. Taki system udostępnia na swojej stronie blisko 90\% gmin. Dla porównania, interaktywną mapę turystyczną posiada na swojej stronie internetowej zaledwie $2 \%$ wszystkich gmin wiejskich województwa łódzkiego. Statyczną mapę turystyczną na swojej stronie internetowej umieściło $12 \%$ gmin, a niewiele więcej, bo $20 \%$ - inną statyczną mapę cyfrową.

Zgodnie z Dyrektywą Unii Europejskiej INSPIRE z 2007 roku oraz jej transpozycją z 2010 roku - Ustawą o infrastrukturze informacji przestrzennej, organy administracji prowadzące rejestry publiczne danych przestrzennych mają 
obowiązek tworzenia cyfrowych sieci usług i udostępniania zbiorów i usług danych przestrzennych (Ślusarski 2012). Dotyczy to także jednostek samorządu terytorialnego, w tym gmin, które mają za zadanie tworzyć i udostępniać systemy informacji przestrzennej. Z przeprowadzonej kwerendy wynika, że $87 \%$ gmin wiejskich województwa łódzkiego posiada system informacji przestrzennej (ryc. 1), przy czym większość udostępnia go za pomocą serwisu e-mapa.net firmy GEO-SYSTEM, która zajmuje się tworzeniem tego typu oprogramowania dla ośrodków dokumentacji geodezyjnej i kartograficznej, urzędów miast, gmin, a także zakładów przemysłowych i wykonawców geodezyjnych.

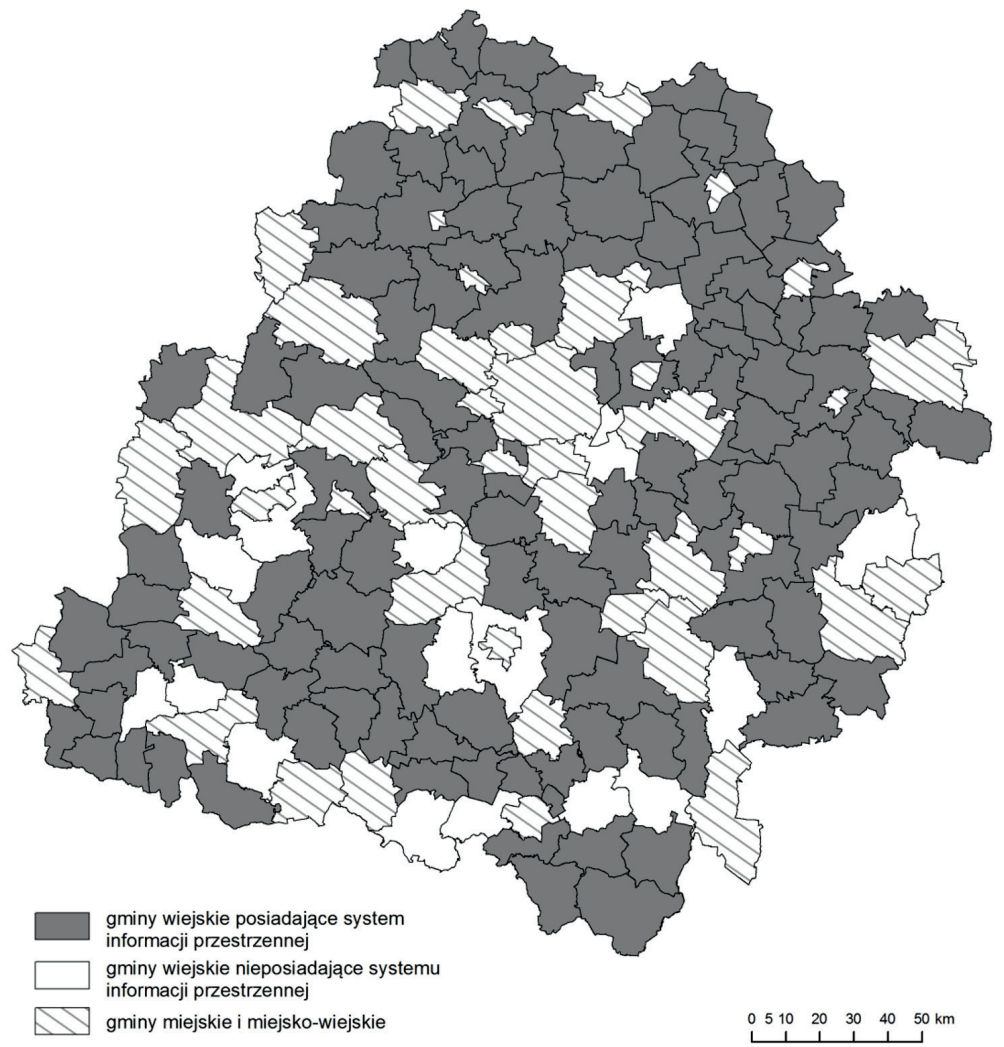

Ryc. 1. Gminy wiejskie województwa łódzkiego posiadające system informacji przestrzennej w 2017 roku

Źródło: opracowanie własne

Serwisy te wyposażone są w panel warstw informacyjnych, pasek narzędziowy, funkcje zmiany widoku oraz wyszukiwanie. Umożliwiają także m.in. dokonanie pomiaru odległości i powierzchni, wydruku mapy, selekcji wielu obiektów, a także dodania nowego serwisu WMS. Niestety, systemy informacji przestrzen- 
nej gmin wiejskich województwa łódzkiego udostępniają niewiele własnych danych, a głównie dane prezentowane przez zewnętrzne serwisy, takie jak: Generalna Dyrekcja Ochrony Środowiska, Bank Danych o Lasach, OpenStreetMap, Państwowy Instytut Geologiczny, Narodowy Instytut Dziedzictwa, Krajowy Zarząd Gospodarki Wodnej, Monitoring Obiektów Ruchomych i Geoportal. Niewielka ilość danych czyni te systemy niezbyt atrakcyjnym źródłem informacji, szczególnie dla potencjalnego turysty.

Przeprowadzona kwerenda wskazała, że zaledwie trzy gminy posiadają interaktywne mapy turystyczne (ryc. 2). Są to gminy: Oporów, Nowosolna i Żarnów.

Interaktywna mapa atrakcji turystycznych gminy Oporów stworzona jest przy użyciu aplikacji Moje Mapy Google, która umożliwia tworzenie i edycję map w sieci na podkładzie map Google. Pozwala wyszukać określone miejsce i zaznaczać je na mapie za pomocą jednego znacznika. Dodatkowo można także umieszczać zdjęcia oraz krótkie opisy lub linki do stron internetowych. Mapa gminy Oporów zawiera 11 obiektów: muzeum, stajnię, pałac, 2 parafie, 4 dwory oraz 2 cmentarze. Do obiektów dołączone są zdjęcia i dane adresowe lub link do innej strony internetowej z opisem tekstowym. Mapa posiada funkcję zmiany parametrów widoku oraz zmiany podkładu, a także możliwość udostępnienia określonym użytkownikom. Serwis jest prosty w obsłudze, jednak posiada mało funkcji interaktywnych, a przede wszystkim zawiera niewielką ilość danych, przez co traci na atrakcyjności przekazu.

Interaktywna mapa gminy Nowosolna powstała przy użyciu internetowej aplikacji do tworzenia i zarządzania mapami interaktywnymi - mapCreator opartej na Google Maps Javascript API v3. Aplikacja ta składa się z trzech części:

- panelu zarządzania mapą,

- bazy danych,

- interaktywnej mapy Google.

Stworzona w tej aplikacji mapa gminy Nowosolna posiada podstawową funkcjonalność mapy interaktywnej. Umożliwia zmiany widoku mapy i zmianę treści podkładowej. Obiekty przedstawione na mapie są podzielone na kategorie: biblioteki, cmentarze, kościoły, sklepy spożywcze, straż pożarna, urzędy oraz zabytki, które można włączać i wyłączać z widoku. Niestety, danych jest bardzo mało - łącznie we wszystkich kategoriach przedstawione jest zaledwie 17 obiektów. Dużą wadą tej mapy jest też brak zamieszczonych opisów tekstowych i zdjęć, co znacznie zmniejsza jej atrakcyjność oraz ogranicza możliwości poznania pełnej oferty turystycznej gminy.

Interaktywna mapa walorów turystycznych gminy Żarnów wykonana została w technologii QGISCloud. Jest to platforma WEB-GIS do publikowania map, danych oraz usług w Internecie wraz z pełną funkcjonalnością map interaktywnych. Interaktywna mapa gminy Żarnów umożliwia zmiany widoku oraz zmiany treści podkładowej. Serwis pozwala również dokonywać pomiaru odległości i po- 
wierzchni oraz odczytywać współrzędne i aktualną pozycję GPS. Istnieje także funkcja wyszukiwania obiektów. Na mapie zaprezentowanych zostało 77 obiektów podzielonych na 16 warstw: kościoły, cmentarze, kapliczki, dzwonnice, dwory, domy, chałupy, budynki gospodarcze, parki, rezerwaty przyrody, wzniesienia, zbiorniki wodne, pomniki, grodziska, skały i okopy na podkładzie OpenStreetMap. Opublikowane warstwy można włączać i wyłączać z widoku, ustalać ich przezroczystość, a do każdej z warstw dołączona jest legenda. Dodatkowo każdy obiekt na mapie posiada opis tekstowy oraz link do zdjęcia. Tak duża ilość danych i ich opis bardzo dobrze przedstawiają walory turystyczne gminy, a prosty interfejs i różnorodność funkcji interaktywnych czyni mapę atrakcyjną dla potencjalnego turysty.

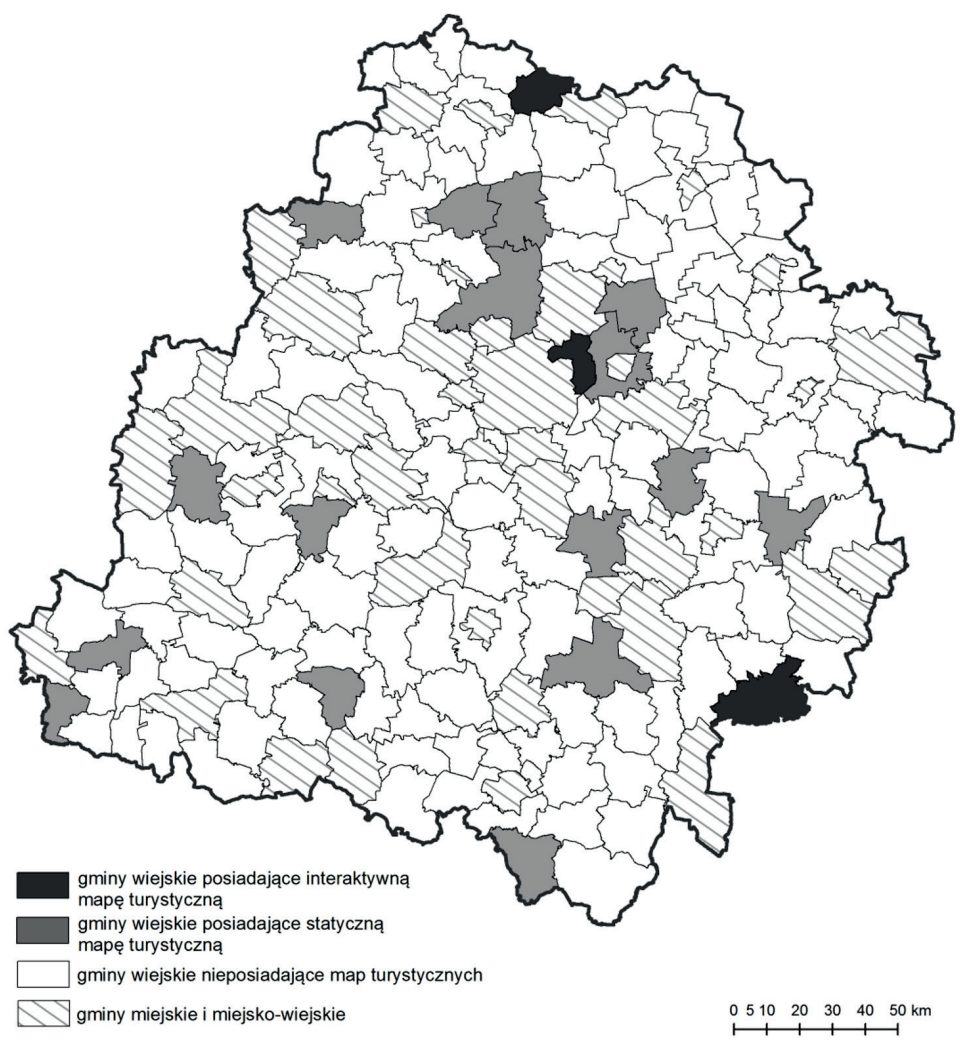

Ryc. 2. Gminy wiejskie województwa łódzkiego posiadające cyfrową mapę turystyczną w 2017 roku

Źródło: opracowanie własne

Spośród 133 gmin wiejskich województwa łódzkiego, 16 gmin oferuje na swojej stronie internetowej turystyczną cyfrową mapę statyczną (ryc. 2), co daje obraz niekompletności treści turystycznej (14\%) na mapach gmin wiejskich 
województwa łódzkiego. Są to pojedyncze gminy rozmieszczone dość równomiernie w województwie łódzkim lub niewielkie zwarte obszary liczące do 3 gmin: Góra Świętej Małgorzaty, Piątek, Zgierz oraz Dmosin, Brzeziny i Nowosolna. Może to świadczyć o początkach dyfuzji innowacji.

Część gmin wiejskich województwa łódzkiego posiada na swojej stronie internetowej statyczną mapę cyfrową nieposiadającą treści turystycznej, głównie prostą mapę lokalizacyjną (ryc. 3). Są to zazwyczaj gminy rozmieszczone na obszarze województwa łódzkiego pojedynczo, rzadziej tworzące zwarte obszary liczące dwie lub trzy sąsiadujące ze sobą gminy. Na 65\% z ogólnej liczby nieturystycznych map gmin zamieszczonych w Internecie, znaleźć można także treść turystyczną mającą charakter informacji uzupełniającej zasadniczą tematykę mapy (ryc. 3). Łącznie informacje turystyczne są umieszczone na mapach w $24 \%$ gmin wiejskich województwa łódzkiego.

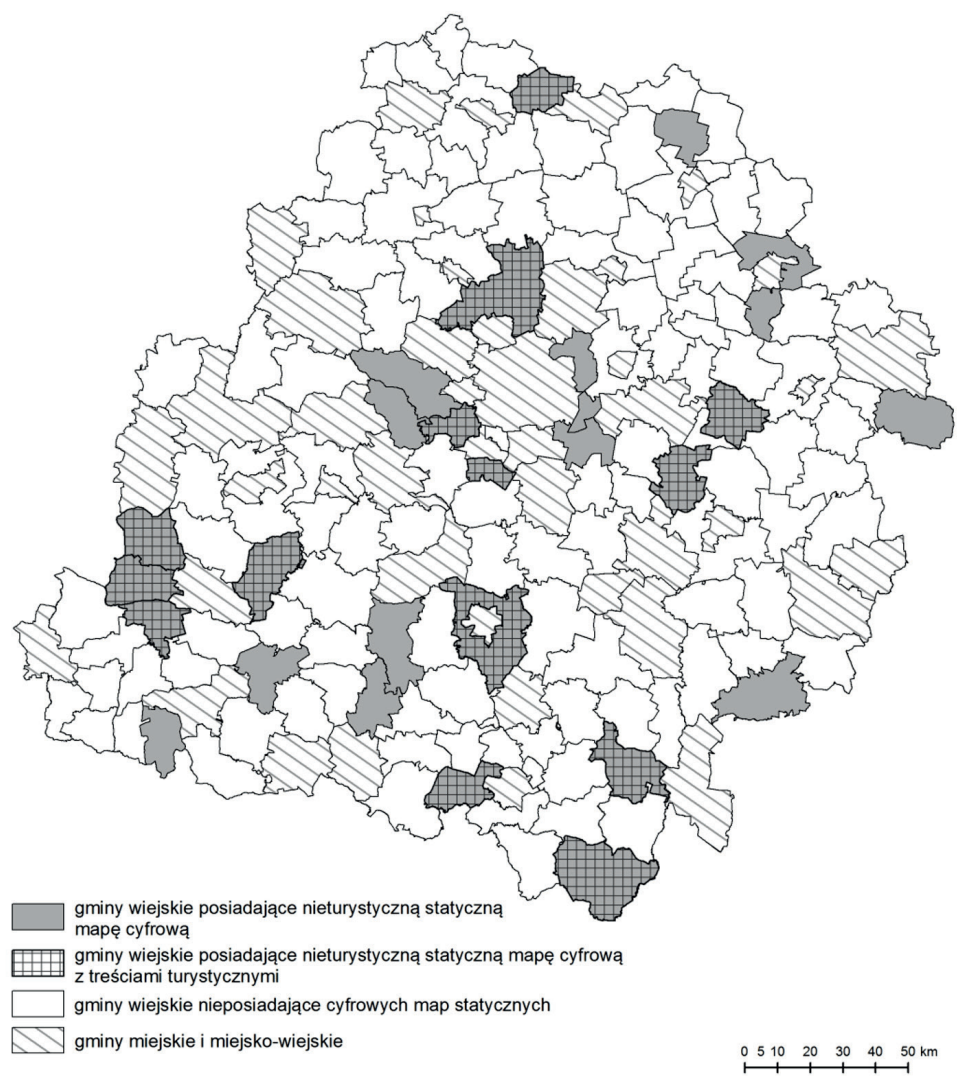

Ryc. 3. Gminy wiejskie województwa łódzkiego posiadające nieturystyczną statyczną mapę cyfrową w 2017 roku

Źródło: opracowanie własne 


\section{Podsumowanie}

Postęp technologiczny i związany z nim rozwój Internetu i serwerów mapowych doprowadził do rozpowszechnienia cyfrowych map interaktywnych, które łączą zalety mapy tradycyjnej z wymaganiami dzisiejszych użytkowników. Szczególnie dobrze widoczne jest to w przypadku map turystycznych. Rozwój turystyki na określonym obszarze jest coraz częściej związany z wykorzystaniem innowacyjnych i kreatywnych produktów turystycznych. Interesującym produktem i formą promocji może być interaktywna mapa turystyczna. Przeprowadzono badania dotyczące wykorzystania cyfrowych map turystycznych w 133 gminach wiejskich województwa łódzkiego. Coraz więcej gmin posiada systemy informacji przestrzennej, jednak serwisy te prezentują głównie dane zewnętrznych serwisów WMS, przez co systemy te tracą na atrakcyjności. Treści turystyczne na mapach cyfrowych obszarów wiejskich województwa łódzkiego można odnaleźć na portalach ogólnopolskich, wojewódzkich oraz umieszczonych na własnych stronach internetowych gmin. Szczególnie atrakcyjnym dla odbiorcy rozwiązaniem przedstawienia informacji turystycznych w Internecie są interaktywne mapy turystyczne, które pozwalają na lepsze poznanie oferty turystycznej obszaru dzięki wzbogaceniu treści mapy opisami tekstowymi i ilustracją fotograficzną, a także zastosowaniu wielu różnorodnych interaktywnych funkcji. Dużą rolę w promocji turystyki tych gmin odgrywają serwis turystykawgminie.pl oraz portal turystyki aktywnej map4u.pl. Nie bez znaczenia są również serwisy o zasięgu wojewódzkim: visitlodzkie.pl, dev.wsiodle.lodzkie.pl i kultura.lodz.pl. Oprócz tych interaktywnych map turystycznych gminy wiejskie rzadko posiadają własne mapy tego typu. Interaktywne mapy turystyczne mają na swojej stronie internetowej jedynie 3 spośród 133 gmin wiejskich województwa łódzkiego, co stanowi niewiele ponad $2 \%$. Statyczne cyfrowe mapy turystyczne posiada zaledwie $12 \%$ gmin. Dodatkowo część gmin udostępnia treści turystyczne na innych cyfrowych mapach statycznych umieszczonych na swoich stronach internetowych. Łącznie treści turystyczne znajdują się na mapach $24 \%$ gmin wiejskich województwa łódzkiego. Dużym problemem jest niezadawalająca ilość danych zawartych na mapach turystycznych. Zwykle na cyfrowych mapach turystycznych gmin wiejskich województwa łódzkiego umieszczonych jest zaledwie kilka lub kilkanaście obiektów będących głównymi atrakcjami turystycznymi obszaru, które występują równocześnie w różnych serwisach. Uboga treść cyfrowych map turystycznych powoduje ich niewielkie wykorzystanie w praktyce i we wspieraniu rozwoju obszarów wiejskich. Zwiększenie ilości prezentowanych danych zdecydowanie poprawiłoby ich atrakcyjność. Przeprowadzone badania nie pozwalają na ocenę wykorzystania cyfrowych map turystycznych w szerokim rozumieniu uwzględniającym rzeczywiste efekty dla rozwoju turystyki, a jedynie umożliwiają sprawdzenie ich użycia przez gminy wiejskie. Na obszarach wiejskich 
województwa łódzkiego rzadko wykorzystuje się cyfrowe mapy turystyczne, co może świadczyć o niskiej świadomości ich potencjału w promocji gminy oraz edukacji i rozpowszechnianiu informacji dla mieszkańców. Można jednak zauważyć pierwsze przykłady wykorzystania możliwości cyfrowych map turystycznych, co jest dobrą prognozą na przyszłość.

\section{Literatura}

Bański J., 2004, Możliwości rozwoju alternatywnych źródet dochodu na obszarach wiejskich, [w:] Pałka E. (red.), Pozarolnicza działalność gospodarcza na obszarach wiejskich, Polskie Towarzystwo Geograficzne, Warszawa: 9-22.

Davis D.E., 2004, GIS dla każdego, Wydawnictwo MIKOM, Warszawa.

Falkowski J., 2015, Geografia wsi - próba ujęcia systemowego, „Studia Obszarów Wiejskich", 37: 91-114.

Feltynowski M., 2009, Polityka przestrzenna obszarów wiejskich $w$ kierunku wielofunkcyjnego rozwoju, CeDeWu Sp. z o.o., Warszawa.

Gaździcki J., 2001, Leksykon geomatyczny, Wieś Jutra, Warszawa.

Gotlib D., Iwaniak A., Olszewski R., 2007, GIS: obszary zastosowań, Wydawnictwo Naukowe PWN, Warszawa.

Jaworska O., 2014, Metodyka opracowania portalu geoinformacyjnego z u̇̇yciem oprogramowania typu Open Source na przykładzie serwisu WWW Muzeum na Majdanku, „Polski Przegląd Kartograficzny”, 46(4): 397-411.

Jażdżewska I., 2010, Zastosowanie Systemów Informacji Geograficznej (GIS) w zachowaniu dziedzictwa kulturowego, [w:] Więcek B., Perkowski J. (red.), Rola nauki w zachowaniu dziedzictwa kulturowego: wspótpraca między uczelniami wyższymi a muzeami, archiwami i stużbami konserwatorskimi na terenie regionu tódzkiego, Wydawnictwo Politechniki Łódzkiej, Łódź: 167-183.

Jędrysiak T., 2010, Wiejska turystyka kulturowa, Polskie Wydawnictwo Ekonomiczne, Warszawa.

Kaczmarek J., Stasiak A., Włodarczyk B., 2005, Produkt turystyczny. Pomyst, organizacja, zarzadzanie, Polskie Wydawnictwo Ekonomiczne, Warszawa.

Karnafel-Wyka E., 2011, Turystyka wiejska szansa rozwoju obszarów wiejskich, [w:] Jastrzębski C. (red.), Turystyka wiejska na drodze do komercjalizacji, Wydawnictwo Wyższej Szkoły Ekonomii i Prawa im. Prof. Edwarda Lipińskiego w Kielcach, Kielce: 19-21.

Kowalski P.J., 2000, Polska kartografia w Internecie, [w:] Kartografia polska u progu XXI wieku, XXVII Ogólnopolska Konferencja Kartograficzna, Główny Urząd Geodezji i Kartografii, Warszawa: 265-289.

Kowalski P.J., 2012, Mapa jako praktyczny interfejs serwisu internetowego, „Archiwum Fotogrametrii, Kartografii i Teledetekcji”, 23: 159-168.

Kubik T., 2009, GIS - rozwiazania sieciowe, Wydawnictwo Naukowe PWN, Warszawa.

Longley P.A., Goodchild M.F., Maguire D.J., Rhind D.W., 2006, GIS. Teoria i praktyka, Wydawnictwo Naukowe PWN, Warszawa.

Marciniuk-Kluska A., 2014, Turystyka jako determinanta rozwoju obszarów wiejskich, „Zeszyty Naukowe Uniwersytetu Przyrodniczo-Humanistycznego w Siedlcach”, 101: 85-100. 
Niedzielski E., 2015, Funkcje obszarów wiejskich i ich rozwój, „Zagadnienia Ekonomiki Rolnej”, 2: 84-93.

Nielsen J., 2003, Projektowanie funkcjonalnych serwisów internetowych, Helion, Gliwice.

Soliński T., 2010, Innowacyjne zarządzanie rozwojem turystyki, [w:] Krupa J. (red.), Innowacyjność $w$ turystyce, PRO-CARPATHIA, Rzeszów.

Ślusarski M., 2012, Propozycja oceny geoportali internetowych poziomu lokalnego, „Infrastruktura i Ekologia Terenów Wiejskich”, 1/III/2012: 109-115.

Wojciechowska J., 2006, Geneza oraz ewolucja turystyki na obszarach wiejskich w Polsce, „Folia Turistica”, 17: 99-119.

Wojciechowska J., 2010, Agroturystyka - signum polskiej turystyki, „Acta Scientiarum Polonorum. Oeconomia", 9(4): 597-606.

Wójcik M., 2013, Koncepcje i problemy badawcze w geografii wsi, „Acta Universitatis Lodziensis. Folia Geographica Socio-Oeconomica", 13: 3-17.

Ziółkowski R., 2007, Zarządzanie informacja $w$ regionie turystycznym, Wydawnictwo Politechniki Białostockiej, Białystok.

\title{
THE USE OF DIGITAL TOURIST MAP TO SUPPORT THE DEVELOPMENT OF TOURISM IN RURAL AREAS, ILLUSTRATED WITH AN EXAMPLE OF LÓDŹ VOIVODESHIP
}

\begin{abstract}
Along with the development of technology and changes in the needs of current map users, digital maps available on the Internet start to play a significant role. Such maps become an attractive tourist product of many regions. The article was aimed at investigating the use of digital tourist maps in rural areas of Łódź Voivodeship. An attempt was made to analyze such maps of communes of Łódź Voivodeship which are available on the Internet. The nationwide, provincial and local websites have been characterized. Both functionality and content of all interactive tourist maps were discussed. Maps of communes presented on their own websites were analyzed in detail, and the results of the query were shown on the maps. Apart from interactive tourist maps offered by nationwide and provincial websites, only 2 percent of all communes in Łódź Voivodeship share such maps on their websites. Other digital maps: tourist as well as all remaining ones presented on the websites of these communes are also not very popular, since only every third rural commune possesses them. What is an important issue is also the quantity and quality of data presented on these maps, which are few and most of which need updating and extending.
\end{abstract}

Keywords: Digital tourist map, interactive digital map, tourism in rural areas, Łódź Voivodeship.

Mgr Angelika Jasion

Zakład Geoinformacji

Instytut Geografii Miast i Turyzmu

Wydział Nauk Geograficznych

Uniwersytet Łódzki

e-mail: angelikajasion@gmail.com 